\title{
Impacts of Short-Term Water Restriction on Pelibuey Sheep: Physiological and Blood Parameters
}

Jorge Orlay Serrano

University of Ciego de Ávila

Asiel Villares-Garachana

University of Ciego de Ávila

Nelson Correa-Herrera

University of Ciego de Ávila

Abel González-Morales

University of Ciego de Ávila

Lisbet Pérez-Bonachea

University of Ciego de Avila

Lázaro Hernández

University of Ciego de Avila

Gustavo Lorente

University of Ciego de Avila

Elliosha Hajari

Agricultural Research Council

Norge Fonseca-Fuentes

Universidad de Granma (UDG)

Jorge Martínez-Melo

University of Ciego de Ávila

José Carlos Lorenzo ( $\boldsymbol{D}$ jclorenzo@bioplantas.cu )

University of Ciego de Ávila https://orcid.org/0000-0003-3610-1789

\section{Research Article}

Keywords: animal physiological stress, climate change, Ovis aries, water stress

Posted Date: July 8th, 2021

DOI: https://doi.org/10.21203/rs.3.rs-648566/v1 
License: (c) (i) This work is licensed under a Creative Commons Attribution 4.0 International License. Read Full License

Version of Record: A version of this preprint was published at Tropical Animal Health and Production on January 10th, 2022. See the published version at https://doi.org/10.1007/s11250-022-03050-9. 


\section{Abstract}

One of the projected effects of climate change is a reduction in rainfall in certain regions of the world. Hence, the agricultural and livestock sectors will have to cope with increasing incidences of water shortage whilst still maintaining productivity levels to feed an ever increasing global population. This short communication reports on the effect of a two week water stress on Pelibuey sheep in Cuba. Three treatments were compared viz. supply of water ad libitum; water supplied once every 3 or $6 \mathrm{~d}$. Following exposure to the water stress, the results showed no changes in sheep body weight or rectal temperature. However, respiration frequency was affected with water stress causing a reduction from 23.3 to 13.3 respirations per min in control and water deprived animals, respectively. Furthermore, there was evidence for hemoconcentration in response to water stress (levels of hemoglobin increased from 9.2 to $13.1 \mathrm{~g} \mathrm{~L}^{-1}$ and hematocrits from 27.6 to $39.3 \%$ in the control group and animals restricted to water once every $6 \mathrm{~d}$. The imposed water stress was also evident in the reduction of lymphocytes (from \pm 63 to $43 \%$ ), and in increase of neutrophils (from approximately 38 to 54\%) and leukocytes (from 3133 to 4933 per $\mathrm{mm}^{3}$ ). The results indicated a decline in the levels of antioxidants, i.e. SOD (SOD from approximately 13 to $10 \mathrm{U}$ $\mathrm{mg}^{-1}$ protein and CAT activity from 23 to $9 \mathrm{U} \mathrm{mg}^{-1}$ protein. To the best of our knowledge, this is the first report on the response of Pelibuey sheep to short-term water shortage stress under Cuban environmental conditions.

\section{Introduction}

Livestock farming contributes towards global food production to feed an ever increasing population. According to the United Nations World Population Prospects (UNO 2019), current projections for population growth estimate an increase of up to 9.7 billion people on the planet by 2050 . There will have to be a concomitant rise in food production to support this growing population. Both agricultural and livestock production are reliant on finite climate-sensitive natural resources, therefore in the case of livestock farming, it is widely accepted that the bulk of this proposed increase in production will have to be addressed by sustainably producing more outputs without accessing additional land and water. This needs to be achieved while maintaining emissions at a minimal level (Herrero et al. 2010; Tilman et al. 2011) and it is critical to ensure that farming endeavors do not expand into vulnerable ecosystems and cause further damage (Naylor 2009; Rockström et al. 2009).

Climate change is driven primarily by the release of greenhouse gases (GHG) into the environment which leads to global warming (IPCC 2013). It is acknowledged that the livestock sector contributes up to $14.5 \%$ towards GHG emissions (Gerber et al. 2013). Although there is much uncertainty surrounding predicted climate change scenarios for the future, one projection estimates an increase of $0.3-4.8^{\circ} \mathrm{C}$ in average surface temperatures by 2100 (IPCC 2013). Some regions of the world are expected to receive less rainfall making water scarcity a concern. Furthermore, the quality of water available will also be in question as, for example, salinization of fresh water aquifers is predicted (Iturralde-Vinent and Méndez 2015). The impacts of changing climate patterns on the livestock sector will have a dual effect on both animal nutrition and well-being. In the context of the former, the availability and quality of feed, forage 
and water will be influenced by increasing temperatures, the predicted rise in carbon dioxide $\left(\mathrm{CO}_{2}\right)$ levels and alterations in rainfall patterns while animal reproduction and health (including disease transmission) will also be affected by similar factors (Rojas-Downing et al. 2017; Escarcha et al. 2018). It is expected that increasing $\mathrm{CO}_{2}$ levels will have variable implications on $\mathrm{C}_{3}$ and $\mathrm{C}_{4}$ plants, thereby influencing the species composition of pastures and forage quality (digestibility of lignin and cell wall constituents, protein content, etc.) (Wand et al. 1999; Sanz-Saez et al. 2012; Polley et al. 2013). As a result, a selfperpetuating cycle is created where livestock farming accelerates climate change which subsequently has adverse effects on animal production. Hence, it is imperative that appropriate management strategies are implemented to ensure efficient food production while preserving the environment and natural resources (Wright et al. 2012).

Water is essential for life, and animal welfare is strongly dependent on a stable supply of this resource (Serrano et al. 2021a; Serrano et al. 2021c; Serrano et al. 2021b). In the context of livestock farming, it is known that sheep and goats display greater resilience to unfavorable environmental conditions than cattle (Louw 1984; Silanikove and Koluman 2015). Sheep, being ruminants like goats, can tolerate the loss of more than $20 \%$ of body water (Jaber et al. 2004), however, the imposition of this stress has implications on animal performance and the maintenance of homeostasis (Abdelatif et al. 1994; Alamer and Al-Hozab 2004). Furthermore, as much of sheep farming is undertaken in arid and semi-arid regions of the world, indigenous species have the ability to out-perform conventional breeds under these adverse conditions (Silanikove 1992). In the present study, Pelibuey sheep were used, this species has become domesticated in Cuba and is also reared in other regions of the Caribbean and Mexico (Gutiérrez et al. 2005; Porter et al. 2016). These sheep produce a coat of hair rather than wool and are well adapted to humid, tropical conditions typified by challenging environmental factors including low feed supply, parasites, etc. These attributes make Pelibuey sheep ideal for farmers in developing countries (Carrillo and Segura 1993). In terms of genetic relationships, it has been suggested that Pelibuey sheep might be related to African breeds or American breeds that originated in Africa (Porter et al. 2016).

Livestock farming contributes towards food production but also requires a significant input of water to achieve this (Serrano et al. 2021a). In the current scenario of constrained water resources with predictions of further declines in the future, it is imperative to consider the impacts of a reduction in water supply on high input sectors. In the context of livestock farming the greatest consumption of water is incurred during processing and feed production (Ran et al. 2016). Therefore, it is critical to undertake research to identify vulnerabilities in current production systems as well as opportunities that would enable farmers to develop and implement strategies that would allow for an appropriate response to adverse effects to ensure sustainability of the livestock sector (Leite et al. 2019). The effects of water restriction on animals ultimately leads to reduced productivity, reproductive capability, changes in metabolic functioning and poor overall health (Lucy 2002; Barbour et al. 2005; Jaber et al. 2011; Alhidary et al. 2012; De Vries 2012; Godfrey et al. 2017; Gowane et al. 2017; Abdelsattar et al. 2020). The intensity and duration of the applied stress will determine the severity of the response (Hussein et al. 2020). Small ruminants have an advantage over other animals as they are capable of activating a range of adaptive mechanisms which 
allow them to more efficiently use the available water and thereby minimize adverse effects of the imposed stress (de Moura et al. 2016; Castro et al. 2017). Nevertheless, it is necessary to determine the consequences of the imposition of water scarcity on animal well-being.

The present contribution reports on the effect of a short-term (two week) water stress on Pelibuey sheep. The physiological responses of animals were recorded as well as evaluation of blood chemistry. To the best of our knowledge, this is the first report on the response of Pelibuey sheep to short-term water shortage stress under Cuban conditions.

\section{Materials And Methods}

The trial was undertaken at the Field Experimental Station of the Bioplant Centre, University of Ciego de Ávila, Cuba ( $2152^{\prime} 48.6^{\prime \prime} \mathrm{N}, 78$ 41'32.6" W; 53 meters above sea level) on Ferralytic-red soil. The animals used in the trial were young male Pelibuey sheep in good health that were 5 to 6 months old with a mass of between 12 and $17 \mathrm{~kg}$. For exposure to the water stress; three levels of supply were compared: 1) water supplied ad libitum; 2 ) water supplied for 4 hours (h) (8:00-12:00) every 3 days (day 1, 4, 7, 10 and 13); and water supplied for $4 \mathrm{~h}$ (8:00-12:00) every 6 days (day 1, 7 and 13). There were three replicates of three animals for each tested treatment ( 9 animals per treatment) and evaluations were recorded on the last day of the trial (day 14).

For the duration of the trial, animals were confined in pens with shade provided and with a living space of $2 \mathrm{~m}^{2}$ allocated per animal. Sheep were provided with ground forage comprised of Pennisetum purpureum and Saccharum officinarum (1: 1, v: v) with $2.5 \mathrm{~kg}$ of fresh mass supplied to each animal daily. In order to ensure that all animals were fed at the same time, linear feeders were used (at a distance of $50 \mathrm{~cm}$ from the front of the feeder per animal). For the provision of water, animals in each treatment had access to individual drinkers. Ambient temperatures were between 19.7 and $33.4{ }^{\circ} \mathrm{C}$, with a relative humidity of 72 to $97 \%$ (during May 2021).

A range of physiological indicators were measured to assess the response of sheep to the reduced water supply. This included body weight (Alfa Laval Agri, $5 \mathrm{~kg} \pm 1 \mathrm{~g}$ ), body weight increase per day [calculated as (final weight - initial weight)/14 d)]; rectal temperature recorded at 14:00 h (Sharma et al. 2013; Cerqueira et al. 2016); respiration frequency (Casamassima et al. 2016); and biochemical markers, i.e. levels of hemoglobin, hematocrits, lymphocytes, neutrophils, leukocytes, soluble proteins, and specific activities of superoxide dismutase (SOD) and catalase (CAT) in blood samples. For the measurement of blood parameters, samples were taken by venipuncture (between 8:30 and 9:00) in a tube with an anticoagulant [(20 mmol L-1 ehtylenediaminetetraacetic acid (EDTA)] to assess the hematology of the blood (Huerta Aragonés and Cela de Julián 2018).

To measure levels of soluble proteins, SOD and CAT specific activities; an aliquot $(1.5 \mathrm{~mL})$ of the blood sample supplemented with anti-coagulant was centrifuged at $20000 \times \mathrm{g}$ for $5 \mathrm{~min}$ at $4^{\circ} \mathrm{C}$ (Heal Force ${ }^{\circledR}$, Neofuge 15R). The supernatant was discarded and the precipitate was washed three times with isotonic 
saline serum [0.9\% $\mathrm{NaCl}(\mathrm{w}: \mathrm{v})]$. The precipitated red blood cells were diluted (1:4, v:v) with distilled water. The diluted samples were frozen at $-6^{\circ} \mathrm{C}$ for $30 \mathrm{~min}$ and then re-warmed to obtain hemolyzed samples which were stored at $2{ }^{\circ} \mathrm{C}$ until further analysis. To measure levels of soluble proteins and activities of enzymes, hemolyzed samples were supplemented with $50 \mathrm{mM} \mathrm{KH}_{2} \mathrm{PO}_{4}-\mathrm{KOH}[\mathrm{pH} 7.1 ; 1: 500$ (v:v)].

Levels of soluble proteins were determined according to the Bradford method (1976). A $20 \mu \mathrm{L}$ aliquot of sample was supplemented with $1000 \mu \mathrm{L}$ of Bradford reagent and the absorbance was measured at 595 $\mathrm{nm}$ following a 20 min incubation period. Bovine serum albumin (fraction $\mathrm{V}$ ) was used as a standard.

The CAT (EC 1.11.1.6) specific activity was measured according to Aebi (1984). One $\mathrm{mL}$ of red blood cells and $0.5 \mathrm{~mL}$ of $\mathrm{H}_{2} \mathrm{O}_{2}(15 \mathrm{mM})$ were combined in a quartz cuvette and the decomposition of $\mathrm{H}_{2} \mathrm{O}_{2}$ was evaluated at $240 \mathrm{~nm}$ and at $25^{\circ} \mathrm{C}$ for $30 \mathrm{~s}$. The CAT activity was determined using the molar extinction coefficient of $\mathrm{H}_{2} \mathrm{O}_{2}\left(\varepsilon=0.0436 \mu \mathrm{M}^{-1} \mathrm{~cm}^{-1}\right)$. A unit of enzymatic activity was defined as the amount of catalase that degraded $1 \mu \mathrm{M}$ of $\mathrm{H}_{2} \mathrm{O}_{2}$ per min.

The SOD (EC 1.15.1.1) specific activity was determined by the inhibition of the auto-oxidation of pyrogallol (Marklund and Marklund 1974). In this method, $400 \mu \mathrm{L}$ of red blood cells were added to a glass cuvette, thereafter $530 \mu \mathrm{L}$ of TRIS-HCl $(50 \mathrm{mM}, \mathrm{pH} 8.2)$, and $70 \mu \mathrm{L}$ of bovine liver catalase $(0.3 \mathrm{U} / \mathrm{mL}$, Sigma-Aldrich) were added. The reaction was initiated by the addition of $0.13 \mathrm{mM}$ pyrogallol (SigmaAldrich). The reaction was permitted to proceed at $25^{\circ} \mathrm{C}$ for $90 \mathrm{~s}$ and thereafter the decomposition kinetics of pyrogallol at $420 \mathrm{~nm}$ was measured for $60 \mathrm{~s}$. A unit of superoxide dismutase was defined as the amount of enzyme capable of reducing the auto-oxidation of pyrogallol by $50 \%$.

All data collected were statistically analyzed using SPSS (Version 8.0 for Windows, SPSS Inc., New York). Analysis of Variance (ANOVA) and Tukey tests $(p<0.05)$ were performed to identify significant differences between treatments.

\section{Results}

Studies have demonstrated the adaptability of sheep and the physiological defense mechanisms engaged in the stress response (Al-Ramamneh et al. 2012; Kumar et al. 2016; Ghassemi and Sung 2017). Water stress, like any form of stress, produces disturbances in the general state of health and well-being of the animal and constitutes a limiting factor in the productive performance of the species. The present contribution reports on the response of Pelibuey sheep to the imposition of a two week water stress. The results showed that there was no discernible change in the body weight of animals in response to water restriction (Fig. 1a). However, water restriction reduced body weight increase per day from 0.052 to 0.012 $\mathrm{kg} \mathrm{d}^{-1}$ (Fig. 1b). The temperature of animals remained consistent irrespective of the amount of water consumed (Fig. 1C). However, the respiratory rate was found to be the significantly highest in animals that had constant access to water, intermediate in those supplied with water every three days and the significantly lowest in those having access to the least amount of water (i.e. once every six days) (Fig. 1d). 
When the blood parameters were measured, it was found that the levels of hemoglobin and hematocrits were significantly highest in those animals supplied with water every $6 \mathrm{~d}$ (Fig. 2a, b) while the levels of these were similar in the other two treatments. Overall, the amount of hemoglobin in blood increased from $9.2 \mathrm{~g} \mathrm{~L}^{-1}$ in sheep supplied with regular access to water and those watered every $3 \mathrm{~d}$ up to $13.1 \mathrm{~g} \mathrm{~L}^{-}$

1 in animals that had water every $6 \mathrm{~d}$. Similarly, hematocrit levels rose from $27.6 \%$ (in sheep exposed to no water limitation and those receiving water every $3 \mathrm{~d}$ ) to $39.3 \%$ in those supplied with the least amount of water. In contrast, lymphocytes (Fig. 2c) were highest in sheep without water restrictions (63\%) and lowest in sheep that were exposed to limited water supply (approximately 43\%). The trend observed in neutrophils (Fig. 2d) and leukocytes (Fig. 2e) were similar as all animals that faced water restrictions displayed significantly higher levels for both measurements $( \pm 54 \%$ for neutrophils and 4933 leukocytes per $\mathrm{mm}^{3}$ ) than the control treatment ( $38 \%$ for neutrophils and 3133 leukocytes per $\mathrm{mm}^{3}$ ).

The level of proteins in the blood were significantly highest in sheep supplied with water every $3 \mathrm{~d}$ (Fig. 3a; $237 \mathrm{mg} \mathrm{mL}^{-1}$ ) while there was no difference in the remaining two treatments. When antioxidants in blood were considered, the ad libitum treatment resulted in the highest levels of SOD (Fig. 3b) and CAT (Fig. 3c) specific activity (13 and $23 \mathrm{U} \mathrm{mg}^{-1}$ protein, respectively) compared with animals with restricted water which displayed similarly low levels.

\section{Discussion}

Access to water is one of the primary requirements for animal well-being and productivity. The results from the present study showed that short-term restriction in water supply did not affect the weight of animals. This could be related to the short duration of the imposed water stress in the current work (two weeks) as similarly reported by Vosooghi-Postindoz et al. (2018). In longer-term trials it is common for a reduction in body weight to be observed as feed intake is closely related to water supply which both subsequently influence weight gained or lost (Chedid et al. 2014). Observations of rectal (core) body temperature and respiration rate provide an indication of the thermoregulatory response of animals (Chedid et al. 2014). The rectal temperature of animals was not affected by the short-term imposed water stress. Similar results were reported by others with different breeds of sheep, for example, Jaber et al. (2004) and Casamassima et al. (2016). However, as highlighted by Chedid et al. (2014), others have reported contrasting results, i.e. notable increases in rectal temperature in response to water stress. This could be related not only to prevailing environmental conditions (temperature and relative humidity) but also specific breeds, exposure to radiation, etc.

The ability to maintain normal respiratory rates following exposure to an applied stress is indicative of tolerance to the imposed stress (Hales 1973). Sheep that display symptoms of water stress reportedly reduce respiratory/panting rates in order to prevent further water loss (McKinley et al. 2009; AlRamamneh et al. 2012; Ghassemi and Sung 2017; Vosooghi-Postindoz et al. 2018). The restriction of water in the diet of animals, could translate into reduce blood circulation, impede the exchange of nutrients and restrict basal metabolism, with a consequent reduction in energy production. These results 
are supported by Al-Ramamneh et al. (2012), Ghassemi and Sung (2017) and Vosooghi-Postindoz et al. (2018) in studies on water restriction, salinity, and ruminal digestibility in sheep. In the current trial, it was observed that the respiratory rate of sheep declined with the imposition of increasing levels of water stress (Fig. 1d from 23.3 to 13.3 respirations per min in control and water stressed animals, respectively). This could suggest a thermoregulatory adaptation to cope with water stress, as discussed above.

The blood chemistry of animals can also be influenced by environmental variables and therefore is routinely measured to follow the progression of the physiological responses of animals to stresses (Okoruwa 2014). It is noted that the average hemoglobin levels of sheep exposed to limited water supply and the control group, from our study were within the normal reference ranges of 9 to $16 \mathrm{~g} \mathrm{~L}^{-1}$ (Wang et al. 2015; Ahmadi-hamedani et al. 2016). Sejian et al. (2017) highlighted that determinations of hematocrit (packed cell volume) and hemoglobin levels provide good indications of thermo tolerance in sheep as these factors correlate with the body water balance. In the current study, hemoglobin and hematocrit levels displayed a similar trend - they were stable in the control and $3 \mathrm{~d}$ water restricted treatments but were elevated with further water stress (Fig. 2a and b). Hemoconcentration (i.e. increased hemoglobin and packed cell volume) has been identified as a consequence of water stress in sheep (Abdelatif et al. 1994; Ghanem et al. 2008). However, others have reported conflicting results, e.g. Igbokwe (1993) and Jaber et al. (2004). It has been suggested that the observation of increased hemoglobin levels might be as a result of reduced plasma volume as a direct consequence of water loss (Kaliber et al. 2016; Kumar et al. 2016; Ay and Ulutas 2020). The maintenance of plasma volume levels might be indicative of an adaptive response by animals to tolerate stress (Sneddon 1993) and the inability to maintain levels could suggest some degree of stress. Interestingly, the phenomenons of hemoconcentration and increase in hemoglobin and hematocrit levels have also been noted under conditions of heat stress. It has been suggested that the increase in blood hemoglobin levels may be a consequence of the higher oxygen demand (Okoruwa 2014; Al-Dawood 2017; Ribeiro et al. 2018; Vicente-Pérez et al. 2018). One hypothesis is that the mobilization of fluids into the circulatory system causes hemoconcentration due to the loss of water through evaporative means (Kumar et al. 2016), similar to the hemoconcentration that occurs when there is restriction of drinking water.

Leukocytes are commonly measured as an indicator of stress in vertebrates (Davis et al. 2008). Leukocytosis (describes an increase in the overall number of white blood cells) has been used to infer a stress response (Ots et al. 1998). However, this must be interpreted with caution as while this parameter can indicate whether an animal has been exposed to a comparatively lesser or greater degree of stress, it is not necessarily indicative of the ability of the animal to mount an immune response (Davis et al. 2008). In terms of an immune response, a reduction in leukocyte numbers is typical (Dhabhar 2002). In the current trial, an increase in leukocytes was observed in response to water stress (Fig. 2e). It has been reported that changes associated with stress conditions include an increase in the prevalence of neutrophils (neutrophilia) and a decrease in the lymphocytes (lymphopenia or lymphocytopenia) (Davis et al. 2008). This was apparent in the current work where lymphocyte levels in water deprived animals were reduced relative to the control. The opposite trend was observed for neutrophils. This suggests that 
the imposition of water stress was apparent in the blood chemistry of sheep. The observation of leukocytosis might also be linked the concurrent decrease in SOD activity as this enzyme has been reported to play an important role in defense against the toxicity caused by leukocytopenia that appears in infections associated with the generation of free radicals (Flores and Medina 2013). Donia et al. (2014) also observed lower serum activity of SOD in pneumonic sheep.

Some researchers have reported an increase in protein levels in response to water stress in sheep, e.g. Jaber et al. (2004), Nejad et al. (2014), Casamassima et al. (2016), Vosooghi-Postindoz et al. (2018), etc. This was attributed to hemoconcentration due to water loss (Casamassima et al. 2016). The observed results were inconsistent in the present study since blood protein levels increased in sheep supplied with water every $3 \mathrm{~d}$ but declined to levels similar to the control in those supplied with water every $6 \mathrm{~d}$ (Fig. 3a).

It has been well established that Reactive Oxygen Species (ROS) are produced in response to stress conditions. Animals possess a suite of antioxidant systems which allow for the quenching of ROS (Halliwell and Gutteridege 2007). When ROS are produced in excess (or are not adequately quenched) oxidative damage results leading to membrane deterioration, protein, DNA and RNA denaturation, etc. (Mujahid et al. 2007). Superoxide dismutase (SOD) and catalase (CAT) are two antioxidants. Superoxide dismutase catalyzes the breakdown of the oxygen radical leading to the generation of $\mathrm{H}_{2} \mathrm{O}_{2}$, which is subsequently decomposed by CAT (Ghosh and Deb 2014). The current study investigated the effect of short-term water stress on the antioxidant capacity of sheep. The results indicated a decline in the levels of both antioxidants (SOD and CAT) when animals were exposed to water limitation. The effect was more pronounced in the case of catalase (Fig. 3c). There has been limited work on the effect of water stress on antioxidant systems in animals as more effort has been focused on heat stress. For example, it has been shown that thermal stress reduced the activity of SOD and CAT in broiler chickens (Zhang et al. 2015). Furthermore, Shi et al. (2020) demonstrated that heat stress resulted in reduced serum levels of CAT in lambs following $28 \mathrm{~d}$ of stress. However, it must be highlighted that the short duration of the water stress imposed in the present study could have been insufficient to trigger protection from antioxidant mechanisms (Rathwa et al. 2017). Furthermore, sheep have other adaptive mechanisms that largely mitigate against the negative effects of limiting factors such as lack of water. In addition, reduced SOD activity (Fig. 3b) could also be related to a deficiency of minerals that act as cofactors for the SOD enzyme (Flores et al. 2011). Even in animals under grazing conditions, serum SOD activity can be used as an indicator for the nutritional metabolic balance of certain elements such as copper, manganese and iron (Flores et al. 2011). However, the increase in body weight per day was affected (Fig. 1b), which is related to an impairment of consumption and consequently a decrease in weight gain. This was similar to that described by Akinmoladun et al. (2019) and Ay and Ulutas (2020), which refer to the influence of the type of food and the association of heat stress.

This study reports on the imposition of short-term water stress in Pelibuey sheep. This type of research is critical in order to develop meaningful strategies to protect livestock production in the face of changing climate patterns. The short- and long-term consequences of water scarcity on sheep well-being and 
productivity during different life cycle stages will have ultimately have impacts on the longevity of this important sector in years to come.

\section{Declarations}

Ethics approval and consent to participate: Informed consent was obtained from all individual participants included in the study. Additional informed consent was obtained from all individual participants for whom identifying information is included in this article.

Ethics approval: The Ethical Committee that provides licenses for experiments on animals approved the animal experimentations.

Consent for publication: All authors have read and approved the final manuscript.

Availability of data and material: Not applicable.

Competing interests: Authors do not have any competing interests.

Funding: Not applicable.

Authors contributions: JOS, AVG, NCH, AGM, LPB, LH, GL, EH, NFF, JMM and JCL designed the research; JOS, AVG, NCH, AGM, LPB, LH and GL conducted the experiment; JOS, EH, NFF, JMM and JCL analyzed the data and wrote the paper; and JOS, JMM, EH and JCL had primary responsibility for the final content.

Acknowledgements: This research was supported by the Faculty of Agricultural Sciences and the Bioplant Centre (University of Ciego de Avila, Cuba), the Agricultural Research Council (South Africa), and the University of Granma (Cuba).

\section{References}

1. Abdelatif AM, Muna M, Ahmed M (1994) Water restriction, thermoregulation, blood constituents and endocrine responses in Sudanese desert sheep. J Environ 26:171-180

2. Abdelatif A, Muna M, Ahmed M (1994) Water restriction, thermoregulation, blood constituents and endocrine responses in Sudanese desert sheep. J Environ Manag 26:171-180

3. Abdelsattar M, Hussein AM, El-Ati A, Saleem A (2020) Impacts of saline water stress on livestock production: A review. SVU-Int J Agric Sci 2:1-12. 10.21608/svuijas.2020.67635

4. Aebi H (1984) Catalase in vitro. Meth Enzymol 105:121-126. https://doi.org/10.1016/S00766879(84)05016-3

5. Ahmadi-hamedani M, Ghazvinian K, Atyabi N, Khanalizadeh P, Masoum MA, Ghodrati MS (2016) Hematological reference values of healthy adult Sangsari sheep (Iranian fat-tailed sheep) estimated by Reference Value Advisor. Comp Clinical Pathol 25:459-464 
6. Akinmoladun OF, Muchenje V, Fon FN (2019) Small ruminants: Farmers' hope in a world threatened by water scarcity. Animals 9:456

7. Al-Dawood A (2017) Towards heat stress management in small ruminants - a review. Ann Anim Sci 17:59-88. 10.1515/aoas-2016-0068

8. Al-Ramamneh D, Riek A, Gerken M (2012) Effect of water restriction on drinking behaviour and water intake in German black-head mutton sheep and Boer goats. Animal 6:173-178

9. Alamer M, Al-Hozab A (2004) Effect of water deprivation and season on feed intake, body weight and thermoregulation in Awassi and Najdi sheep breeds in Saudi Arabia. J Arid Environ 59:71-84

10. Alhidary IA, Shini S, Al Jassim RAM, Gaughan JB (2012) Physiological responses of Australian Merino wethers exposed to high heat load. J Anim Sci 90:212-220

11. Ay CD, Ulutas $B$ (2020) The effects of water deprivation-induced dehydration on serum acute phase protein concentrations in sheep. J Hellenic Vet Med Soc 71:2515-2524

12. Barbour E, Rawda N, Banat G, Jaber L, Sleiman F, Hamadeh S (2005) Comparison of immunosuppression in dry and lactating Awassi ewes due to water deprivation stress. Vet Res Comm 29:47-60

13. Bradford MM (1976) A rapid and sensitive method for the quantification of microgram quantities of protein utilising the principle of protein-dye binding. Analyt Biochem 72:248-254. doi:

10.1006/abio.1976.9999

14. Carrillo A, Segura J (1993) Environmental and genetic effects on preweaning growth performance of hair sheep in Mexico. Trop Anim Health Prod 25:173-178

15. Casamassima D, Vizzarri F, Nardoia M, Palazzo M (2016) The effect of water-restriction on various physiological variables in intensively reared Lacaune ewes. Vet Med 61:623-634

16. Castro DP, Yamamoto SM, Araújo GG, Pinheiro RS, Queiroz MA, Albuquerque ÍR, Moura JH (2017) Influence of drinking water salinity on carcass characteristics and meat quality of Santa Inês lambs. Trop Anim Health Prod 49:1095-1100. https://doi.org/10.1007/s11250-017-1289-5

17. Cerqueira JOL, Araújo JPP, Blanco-Penedo I, Cantalapiedra J, Silvestre AMD, Silva SJCR (2016) Predicción de estrés térmico en vacas lecheras mediante indicadores ambientales y fisiológicos. Arch Zootec 65:357-364

18. Chedid M, Jaber LS, Giger-Reverdin S, Duvaux-Ponter C, Hamadeh SK (2014) Review: Water stress in sheep raised under arid conditions. Can J Anim Sci 94:243-257. https://doi.org/10.4141/cjas2013188

19. Davis AK, Maney DL, Maerz JC (2008) The use of leukocyte profiles to measure stress in vertebrates: a review for ecologists. Rev Funct Ecol 22:760772

20. de Moura JHA, de Araújo GGL, Saraiva EP, de Albuquerque I, Turco SHN, Costa SAP, Santos NM (2016) Ingestive behavior of crossbred Santa Inês sheep fed water with different salinity levels. Semina: Ciênc Agr 37:1057-1068. DOI: 10.5433/1679-0359.2016v37n2p1057 
21. De Vries A (2012) Economics of heat stress: Implications for management. Extension America's Research-based Learning Network Accessed May 272021

Available: http://wwwextensionorg/pages/63287/economics-of-heat-stress:-implications-formanagement

22. Dhabhar $F$ (2002) Stress-induced augmentation of immune function-the role of stress hormones, leukcocyte trafficking, and cytokines. Brain Behav Immun 16:785-798

23. Donia G, Wassif I, El Ebissy I (2014) Impact of some environmental factors and microbes causing respiratory diseases on antioxidant levels in small ruminants. Glob Vet 12:299-306. 10.5829/idosi.gv.2014.12.03.8247

24. Escarcha J, Lassa J, Zander K (2018) Livestock under climate change: a systematic review of impacts and adaptation. Clim Risk Manag 6:54 https://doi:10.3390/cli6030054

25. Flores C, Márquez Y, Vilanova L, Mendoza C (2011) Dienos conjugados y malondialdehído como indicadoresde lipoperoxidación en semen de toros "Carora". Rev Vet 22:91 - 94

26. Flores C, Medina C (2013) Papel de las enzimas antioxidantes en la calidad del semen de bovinos y su repercusión en la fertilidad. Bol Méd Postg 29

27. Gerber P, Steinfeld H, Henderson B, Mottet A, Opio C, Dijkman J, Falcucci A, Tempio G (2013) Tackling Climate Change Through Livestock: A Global Assessment of Emissions and Mitigation Opportunities FAO, Rome,

28. Ghanem A, Barbour E, Hamadeh S, Jaber L, Abi Said M (2008) Physiological and chemical responses in water-deprived Awassi ewes treated with vitamin. C J Arid Environ 72:141-149

29. Ghassemi NJ, Sung KI (2017) Behavioral and physiological changes during heat stress in Corriedale ewes exposed to water deprivation. J Anim Sci Technol 59:13. DOI 10.1186/s40781-017-0140-x

30. Ghosh R, Deb P (2014) A study on antioxidant properties of different bioactive compounds. J Drug Delivery Ther 4:105-115

31. Godfrey RW, Preston W, Joseph S, LaPlace L, Hillman P, Gebremedhin K, Lee C, Collier R (2017) Evaluating the impact of breed, pregnancy, and hair coat on body temperature and sweating rate of hair sheep ewes in the tropics. J Anim Sci 95:2936-2942

32. Gowane G, Gadekar Y, Prakash V, Kadam V, Chopra A, Prince L (2017) Climate change impact on sheep production: Growth, milk, wool, and meat. Sheep Production Adapting to Climate Change. Springer, pp 31-69

33. Gutiérrez J, Rubio M, Méndez R (2005) Effects of crossbreeding Mexican Pelibuey sheep with Rambouillet and Suffolk on carcass traits. Meat Sci 70:1-5

34. Hales J (1973) Effects of exposure to hot environments on the regional distribution of blood flow and on cardiorespiratory function in sheep. Pflügers Arch 344:133-148

35. Halliwell B, Gutteridege J (2007) Free Radicals in Biology and Medicine Oxford University Press, New York, 
36. Herrero M, Thornton P, Notenbaert A, Wood S, Msangi S, Freeman H, Bossio D, Dixon J, Peters M, van de Steeg J, Lynam J, Rao P, Macmillan S, Gerard B, McDermott J, Sere C, Rosegrant M (2010) Smart investments in sustainable food production: revisiting mixed crop-livestock systems. Science 327:822-825

37. Huerta Aragonés J, Cela de Julián E (2018) Hematología práctica: interpretación del hemograma y de las pruebas de coagulación Lúa Ediciones, Madrid, pp 507-526.

38. Hussein A, Puchala R, Gipson T, Tadesse D, Wilson B, Goetsch A (2020) Effects of water restriction on feed intake, digestion, and energy utilization in female St. Croix sheep. Vet Anim Sci 10:100132. https://doi.org/10.1016/j.vas.2020.100132

39. Igbokwe I (1993) Haemoconcentration in Yankasa sheep exposed to prolonged water deprivation. Small Rumin Res 12:99-105

40. IPCC (2013) Climate change 2013: The physical science basis. In: Stocker T, Qin D, Plattner G-K, Tignor M, Allen S, Boschung J, Nauels A, Xia Y, Bex V, Midgley P (eds) Contribution of Working Group I to the Fifth Assessment Report of the Intergovernmental Panel on Climate Change. Cambridge University Press, Cambridge and New York, pp 1535

41. Iturralde-Vinent M, Méndez HS (2015) Peligros y vulnerabilidades de la zona marino-costera de Cuba: Estado actual y perspectivas ante el cambio climático hasta el 2100 Editorial Academia,

42. Jaber L, Habre A, Rawda N, Abi Said M, Barbour E, Hamadeh S (2004) The effect of water restriction on certain physiological parameters in Awassi sheep. Small Rumin Res 54:115-120

43. Jaber L, Hanna N, Barbour E, Abi Said M, Rawda N, Chedid M, Hamadeh S (2011) Fat mobilization in water restricted Awassi ewes supplemented with vitamin C. J Arid Environ 75:625-628

44. Kaliber M, Koluman N, Silanikove N (2016) Physiological and behavioral basis for the successful adaptation of goats to severe water restriction under hot environmental conditions. Animal 10:82-88

45. Kumar D, De K, Singh AK, Kumar K, Sahoo A, Naqvi SMK (2016) Effect of water restriction on physiological responses and certain reproductive traits of Malpura ewes in a semiarid tropical environment. J Vet Behav 12:54-59

46. Leite PG, Marques JI, Furtado DA, Neto JPL, de Souza BB, do Nascimento JWB (2019) Ethology, physiological, and ingestive responses of sheep subjected to different temperatures and salinity levels of water. Int J Biomet 63:1091-1098. https://doi.org/10.1007/s00484-019-01724-y

47. Louw G (1984) Water deprivation in herbivores under arid conditions. In: Gilchrist F, Mackie R (eds) Herbivore Nutrition in the Subtropics and Tropics. The Science Press, Craighall, South Africa, pp 106128

48. Lucy MC (2002) Reproductive loss in farm animals during heat stress. Proc 15th Conf Biometeorol Aerobiol 53

49. Marklund S, Marklund G (1974) Involvement of the superoxide anion radical in the autoxidation of pyrogallol and a convenient assay for superoxide dismutase. The FEBS J 47:469-474. https://doi.org/10.1111/j.1432-1033.1974.tb03714.x 
50. McKinley M, Weissenborn F, Mathai M (2009) Drinking-induced thermoregulatory panting in rehydrated sheep: influences of oropharyngeal/esophageal signals, core temperature, and thirst satiety. Am J Physiol Regul Integr Comp Physiol 296:1881-1888

51. Mujahid A, Akiba Y, Warden C, Toyomizu M (2007) Sequential changes in superoxide production, anion carriers and substrate oxidation in skeletal muscle mitochondria of heat-stressed chickens. FEBS Lett 581:3461-3467

52. Naylor R (2009) Managing food production systems for resilience. In: Folke C, Kofinas G, Chapin $F$ (eds) Principles of Ecosystem Stewardship. Springer, New York, pp 259-280

53. Nejad JG, Lohakare J, West J, Sung K (2014) Effects of water restriction after feeding during heat stress on nutrient digestibility, nitrogen balance, blood profile and characteristics in Corriedale ewes. Anim Feed Sci Technol 193:1-8

54. Okoruwa M (2014) Effect of heat stress on thermoregulatory, live bodyweight and physiological responses of dwarf goats in southern Nigeria. Europ Scient $\mathrm{J} 10$

55. Ots I, Murumagi A, Horak P (1998) Haematological health state indices of reproducing Great Tits: methodology and sources of natural variation. Funct Ecol 12:700-707

56. Polley H, Briske D, Morgan J, Wolter K, Bailey D, Brown J (2013) Climate change and North American rangelands: trends, projections, and implications. Rangeland Ecol Manag 66:493-511

57. Porter V, Alderson L, Hall S, Sponenberg D (2016) Mason's World Encyclopedia of Livestock Breeds and Breeding $\mathrm{CABI}$, Wallingford,

58. Ran Y, Lannerstad M, Herrero M, Van Middelaar C, De Boer I (2016) Assessing water resource use in livestock production: a review of methods. Livest Sci 187:68-79

59. Rathwa SD, Vasava A, Pathan M, Madhira S, Patel Y, Pande A (2017) Effect of season on physiological, biochemical, hormonal, and oxidative stress parameters of indigenous sheep. Vet World 10:650. 10.14202/vetworld.2017.650-654

60. Ribeiro MN, Ribeiro NL, Bozzi R, Costa RG (2018) Physiological and biochemical blood variables of goats subjected to heat stress-a review. J Appl Anim Res 46:1036-1041

61. Rockström J, Steffen W, Noone K, Persson A, Chapin F, Lambin E, Lenton T, Scheffer M, Folke C, Schellnhuber H, Nykvist B, de Wit C, Hughes T, van der Leeuw S, Rodhe H, Sorlin S, Snyder P, Costanza R, Svedin U, Falkenmark M, Karlberg L, Corell R, Fabry V, Hansen J, Walker B, Liverman D, Richardson K, Crutzen P, Foley J (2009) Planetary boundaries: exploring the safe operating space for humanity. Ecol Soc 14:32

62. Rojas-Downing M, Nejadhashemi A, Harrigan Y, Woznicki S (2017) Climate change and livestock: impacts, adaptation and mitigation. Clim Risk Manag 16:145-163

63. Sanz-Saez A, Erice G, Aguirreolea J, Muñoz F, Sanchez-Diaz M, Irigoyen J (2012) Alfalfa forage digestibility, quality and yield under future climate change scenarios vary with Sinorhizobium meliloti strain. Plant Physiol 169:782-788

64. Sejian V, Bhatta R, Gaughan J, Malik P, Naqvi S, Lal R (2017) Adapting sheep production to climate change. Sheep Production Adapting to Climate Change. Springer Singapore, Singapore, pp 1-29 
65. Serrano JO, Lorente G, Pérez L, Martínez-Melo J, Hajari E, Fonseca-Fuentes N, Lorenzo JC (2021a) Effect of short-term mild salinity stress on physiological and hematological parameters in sheep. Biologia 101007/s11756-021-00794-x

66. Serrano JO, Villares A, Manuel-Malamba FD, Martínez-Melo J, Mazorra C, Borroto A, Hajari E, Fonseca-Fuentes N, Lorenzo JC (2021b) Hierarchical cluster analysis: a statistical tool to study sheep behavior under heat stress. World J Adv Pharm Life Sci 01:0.01-007. DOI 10.30574/wjapls

67. Serrano JO, Villares A, Manuel-Malamba FD, Martínez-Melo J, Mazorra C, Borroto A, Hajari E, Fonseca-Fuentes N, Lorenzo JC (2021c) Euclidean distance: integrated criteria to study sheep behaviour under heat stress. Not Sci Biol 3: Online-first DOI:1015835/nsb[10859]

68. Sharma S, Ramesh K, Hyder I, Uniyal S, Yadav V, Panda R, Maurya V, Singh G, Kumar P, Mitra A (2013) Effect of melatonin administration on thyroid hormones, cortisol and expression profile of heat shock proteins in goats (Capra hircus) exposed to heat stress. Small Rum Res 112:216-223. https://doi.org/10.1016/j.smallrumres.2012.12.008

69. Shi L, Xu Y, Mao C, Wang Z, Gao S, Jin X, Yan S, Shi B (2020) Effects of heat stress on antioxidant status and immune function and expression of related genes in lambs. Int $\mathrm{J}$ Biometerol 64:20932104

70. Silanikove N (1992) Effects of water scarcity and hot environment on appetite and digestion in ruminants: a review. Livest Prod Sci 30:175-194

71. Silanikove N, Koluman N (2015) Impact of climate change on the dairy industry in temperate zones: predictions on the overall negative impact and on the positive role of dairy goats in adaptation to earth warming. Small Rumin Res 123:27-34

72. Sneddon J (1993) Physiological effects of hypertonic dehydration on body fluid pools in aridadapted mammals. How do Arab-based horses compare. Comp Biochem Physiol 104:201-213

73. Tilman D, Balzer C, Hill J, Befort B (2011) Global food demand and the sustainable intensification of agriculture. Proc Natl Acad Sci USA 50:20260-20264

74. UNO (2019) Revision of world population prospects. https://www.population.un.org/wpp. Accessed 15 June 2021.

75. Vicente-Pérez A, Avendaño-Reyes L, Barajas-Cruz R, Macías-Cruz U, Correa-Calderón A, Vicente-Pérez R, Corrales-Navarro JL, Guerra-Liera JE (2018) Parámetros bioquímicos y hematológicos en ovinos de pelo con y sin sombra bajo condiciones desérticas. Ecosist Rec Agrop 5:259-269

76. Vosooghi-Postindoz V, Tahmasbi A, Naserian AA, Valizade R, Ebrahimi H (2018) Effect of water deprivation and drinking saline water on performance, blood metabolites, nutrient digestibility, and rumen parameters in Baluchi lambs. Iran J Appl Anim Sci 8:445-456

77. Wand S, Midgley G, Jones M, Curtis P (1999) Responses of wild C4 and C3 grass (Poaceae) species to elevated atmospheric $\mathrm{CO}_{2}$ concentrations: a meta-analytic test of current theories and perceptions. Glob Change Biol 5:141-723

78. Wang H, Huang M, Li S, Wang S, Dong S, Cui D, Qi Z, Liu Y (2015) Hematologic, serum biochemical parameters, fatty acid and amino acid of Longissimus dorsi muscles in meat quality of Tibetan 
sheep. Acta Scient Vet 43:1306

79. Wright I, Tarawali S, Blummel M, Gerard B, Teufel N, Herrero M (2012) Integrating crops and livestock in subtropical agricultural systems. J Sci Food Agric 92:1010-1015

80. Zhang J, Hu Z, Lu C, Bai K, Zhang L, Wang T (2015) Effect of various levels of dietary curcumin on meat quality and antioxidant profile of breast muscle in broilers. J Agric Food Chem 63:3880-3886

\section{Figures}
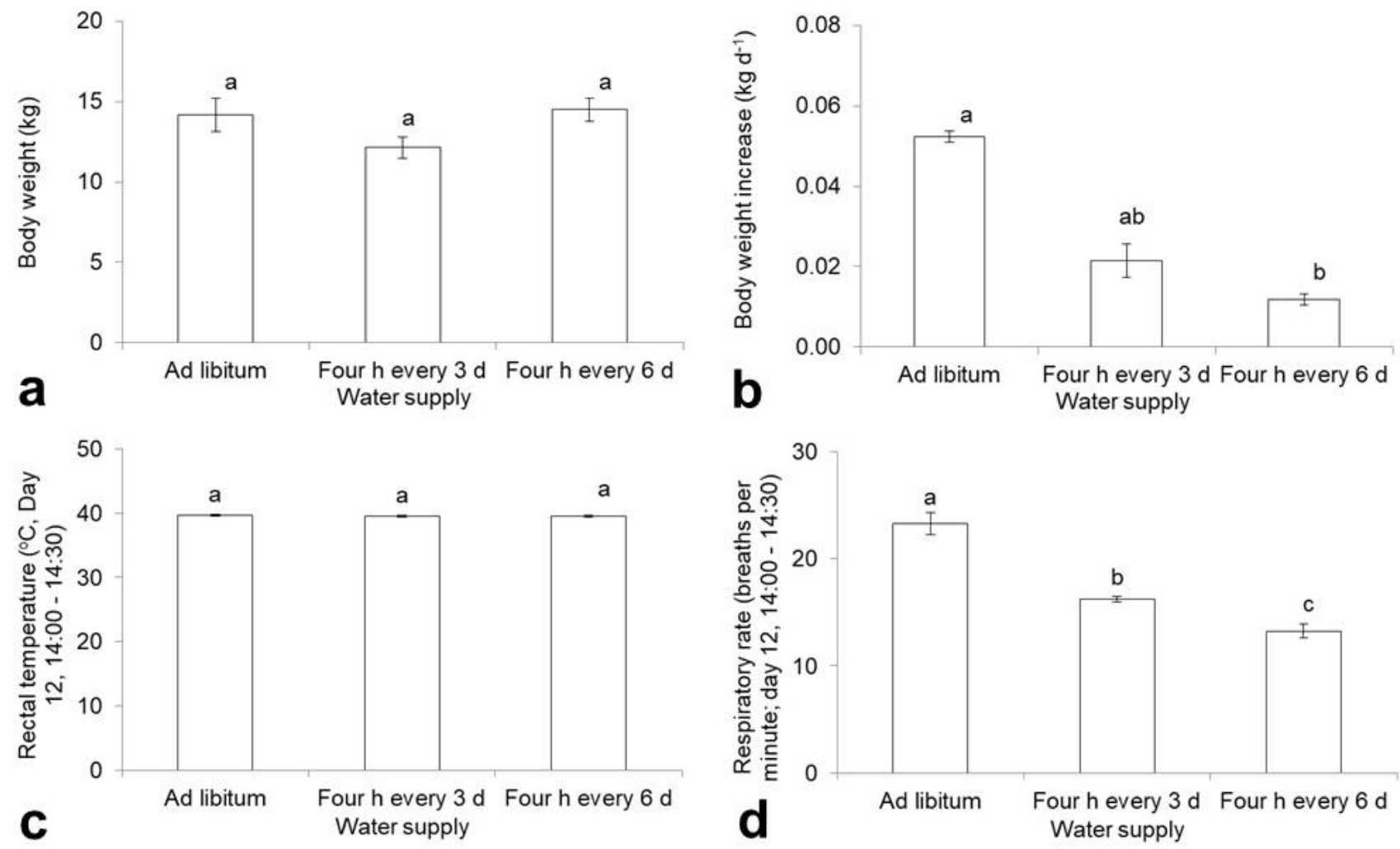

\section{Figure 1}

The results showed that there was no discernible change in the body weight of animals in response to water restriction (Fig. 1a). However, water restriction reduced body weight increase per day from 0.052 to $0.012 \mathrm{~kg} \mathrm{~d}-1$ (Fig. 1b). The temperature of animals remained consistent irrespective of the amount of water consumed (Fig. 1c). However, the respiratory rate was found to be the significantly highest in animals that had constant access to water, intermediate in those supplied with water every three days and the significantly lowest in those having access to the least amount of water (i.e. once every six days) (Fig. 1d). 

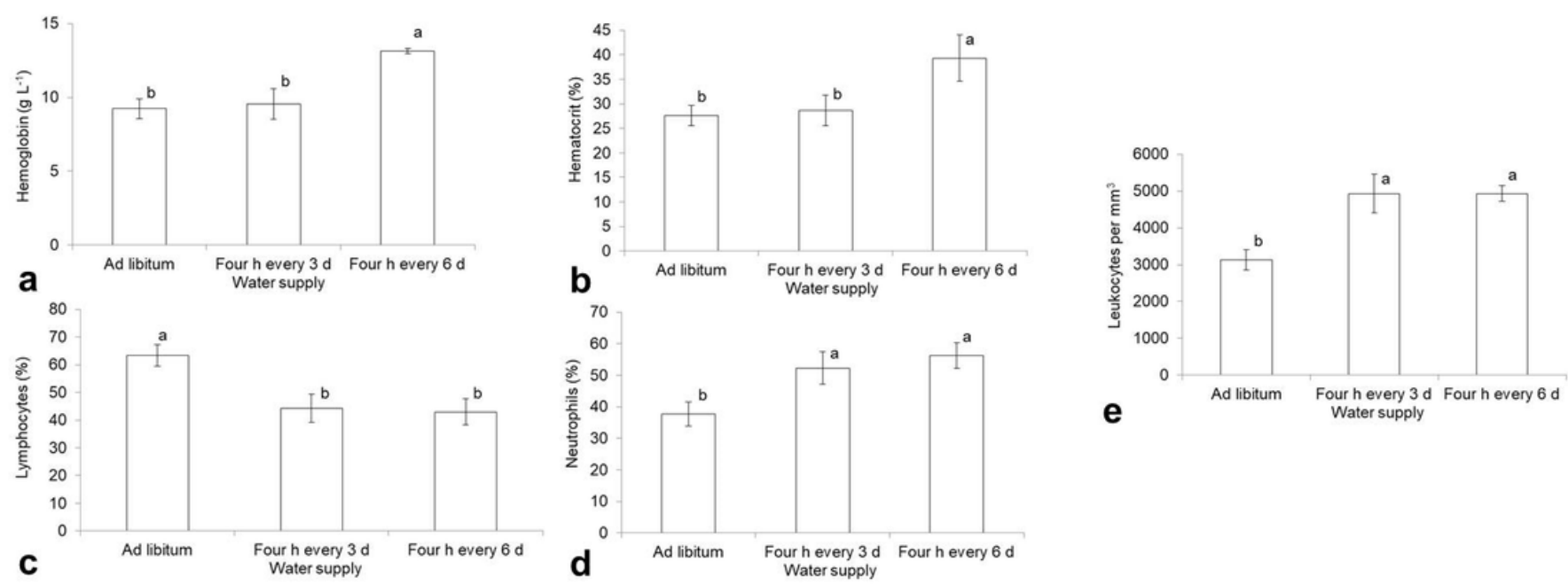

Figure 2

the blood parameters were measured, it was found that the levels of hemoglobin and hematocrits were significantly highest in those animals supplied with water every $6 \mathrm{~d}$ (Fig. 2a, b) while the levels of these were similar in the other two treatments. Overall, the amount of hemoglobin in blood increased from $9.2 \mathrm{~g}$ L-1 in sheep supplied with regular access to water and those watered every $3 \mathrm{~d}$ up to $13.1 \mathrm{~g} \mathrm{~L}-1$ in animals that had water every $6 \mathrm{~d}$. Similarly, hematocrit levels rose from $27.6 \%$ (in sheep exposed to no water limitation and those receiving water every $3 \mathrm{~d}$ ) to $39.3 \%$ in those supplied with the least amount of water. In contrast, lymphocytes (Fig. 2c) were highest in sheep without water restrictions (63\%) and lowest in sheep that were exposed to limited water supply (approximately $43 \%$ ). The trend observed in neutrophils (Fig. 2d) and leukocytes (Fig. 2e) were similar as all animals that faced water restrictions displayed significantly higher levels for both measurements ( $\pm 54 \%$ for neutrophils and 4933 leukocytes per $\mathrm{mm} 3$ ) than the control treatment (38\% for neutrophils and 3133 leukocytes per $\mathrm{mm} 3$ ).
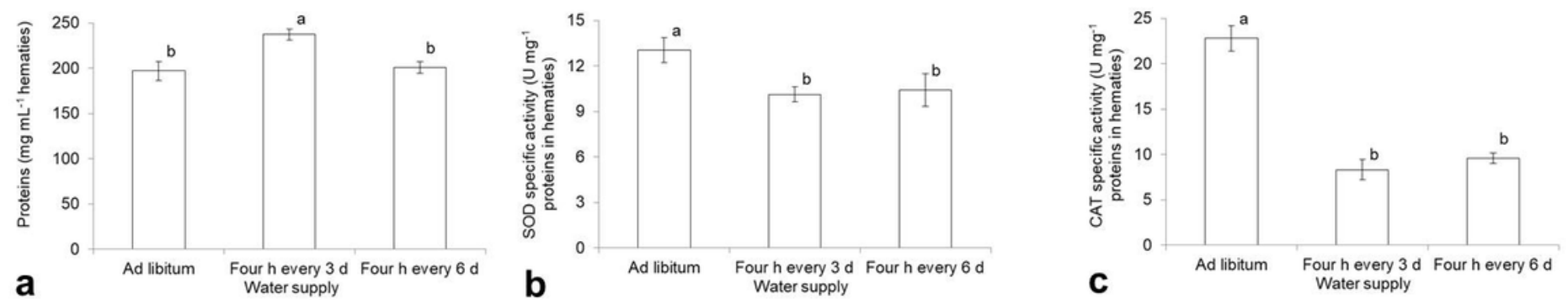

Figure 3

The level of proteins in the blood were significantly highest in sheep supplied with water every $3 \mathrm{~d}$ (Fig. 3a; $237 \mathrm{mg} \mathrm{mL-1)}$ while there was no difference in the remaining two treatments. When antioxidants in 
blood were considered, the ad libitum treatment resulted in the highest levels of SOD (Fig. 3b) and CAT (Fig. 3c) specific activity (13 and $23 \mathrm{U}$ mg-1 protein, respectively) compared with animals with restricted water which displayed similarly low levels. 